\title{
Genetic structure of the population and resistance to infections
}

\author{
Structura genetică a populaţiei şi rezistenţa la infecţii
}

Sorin BUZINSCHI

Facultatea de Medicină, Universitatea „Transilvania“, Braşov, România

\begin{abstract}
- ABSTRACT
Numerous studies have shown that populations behave differently in the face of infections through contagion, evolution, severity and mortality. Both susceptibility and resistance to infections have a strong genetic conditioning. Genetic polymorphisms offer vulnerability/resistance to infectious agents being considered consequences of the evolutionary pressure induced by the co-evolution of germs and population. The study presents examples related to these statements, the most notorious being the mutation of CCR5 delta-32 against HIV infection. Based on the genetic data, explanations are proposed regarding the very different evolution of people in the face of SARS-CoV-2 infection and the chances of an occult immunization of the population.
\end{abstract}

Keywords: genetic variability, inflammatory response sensors, factors that provide resistance to infections, COVID-19 immunity

\begin{abstract}
REZUMAT
Numeroase studii au arătat că populațiile se comportă diferit în fața infecțiilor prin contagiozitate, evoluție, gravitate şi mortalitate. Atât sensibilitatea, cât şi rezistența la infecții au o puternică condiționare genetică. Polimorfismele genetice oferă vulnerabilitate/rezistență în fața agenților infecțioşi, fiind considerate consecințe ale presiunii evolutive induse de coevoluția germenilor ş̧ a populației. Studiul prezintă exemple legate de aceste afirmații, cea mai notorie fiind mutația CCR5 delta-32 față de infecția HIV. În baza datelor genetice, sunt propuse explicații vizând evoluția atât de diferită a persoanelor în fața infecției cu SARS-CoV-2 şi şansele unei imunizări oculte a populației.
\end{abstract}

Cuvinte cheie: variabilitate genetică, senzorii răspunsului inflamator, factori care oferă rezistența la infecții, imunitatea COVID-19

\section{INTRODUCERE}

Modul de prezentare clinică, evoluția bolii, răspunsul la tratament, sechelele postinfecțioase, evoluția severă și mortalitatea sunt influențate de variațiile individuale ale fondului genetic și de modificările epigenetice ale gazdei.
Studiul prezent nu include imunodeficiențele primare, grup heterogen de tulburări caracterizate de absența/exprimarea deficitară a uneia sau a mai multor componente ale sistemului imun, în prezent bine codificate; de asemenea, cele secundare unor afecțiuni cronice. 
În condiții de tratament similar, majoritatea bolnavilor evoluează favorabil, însă un procent mic, dar semnificativ, se agravează (uneori neașteptat) cu insuficiență multiplă de organe și deces (1-3). Cauzele de evoluție nefavorabilă sunt considerate de obicei virulența germenilor, patologia asociată, vârsta, însă suspiciunea vizând calitatea îngrijirilor a fost frecvent invocată. Primele semne de întrebare privind cauzele profunde ale acestor evoluții au fost inițiate de Sorensen, Petersen și colab. $(4,5)$. Folosind datele din Registrul Danez de Adopții, autorii au constatat că subiecții adoptați prezintă un risc de 5 ori mai mare de deces prin infecții dacă părintele natural a murit de o infecție înainte de a împlini 50 de ani. Date concordante asupra gemenilor monozigoți arată că există o componentă genetică care îi expune în mod similar la infecții și deces (6). În anumite afecțiuni, ca tuberculoza, lepra, infecția cu Helicobacter pylori, infecția cronică cu virusul hepatitei $B$, ca și în răspunsul fenotipic la vaccinări, se manifestă o mare concordanță la gemenii monozigoți față de perechile dizigote (13). Prin studii aprofundate asupra genomului uman (Whole Genome Association Study), s-a evidențiat variabilitatea enormă genetică a populațiilor, numeroase gene fiind polimorfe prin mici diferențe în secvența lor de nucleotide (7). În corelație cu datele de epidemiologie genetică, s-au desfășurat studii de biologie moleculară centrate pe polimorfismul pentru un singur nucleotid (SNP) ca explicație pentru creșterea riscului vital în timpul infecțiilor (8). Studiile asupra influenței structurii genetice asupra bolilor infecțioase datează de peste 70 de ani. În 1949, Haldane a lansat ipoteza că bolile infecțioase reprezintă o sursă importantă a selecției naturale umane, avansând ipoteza că malaria reprezintă un modulator al evoluției genetice a populațiilor implicate (9). Infecțiile au jucat un rol major în modularea mortalității în funcție de vârstă. Media de vârstă în epidemiile de rujeolă a fost de 2-5 ani, iar pentru scarlatină între 10 și 14 ani (9), cu procente semnificative de mortalitate în epoca prevaccinală și presiune selectivă precoce. De menționat că, înainte de aplicarea vaccinărilor, epidemiile de rujeolă se succedau la un interval de 1-2 ani, poliomielita la 3-5 ani, difteria la 4-6 ani, gripa epidemică - anual, iar pandemiile - poradic (9). În contrast, unele afecțiuni severe, cum a fost ciuma (bubonic plague), nu au fost legate de o anumită vârstă. Virulența, tradusă prin rata de mortalitate, a fost de circa $90 \%$ pentru Ebola, 30\% pentru variolă, 15\% pentru SARS și 3\% pentru gripa spaniolă (10). Dacă pentru afecțiunile hematologice, ca talasemia, siclemia, deficitul de glucozo-6-dehidrogenază, au fost demonstrate modificări genetice adaptative ale hemoglobinei, nu este clar dacă dispersia epidemică a patogenilor în unele perioade ale istoriei umane a produs variații ale unor gene de rezistență care să contro- leze selecția naturală. Burgner și colab. (11) consideră că bolile infecțioase exercită o presiune selectivă majoră, iar genele implicate în răspunsul imun sunt cele mai numeroase și diverse din genomul uman. Aceste considerente ar indica avantajele evolutive ale răspunsurilor imune variate față de un larg spectru de patogeni (11). Unele exemple ale evoluției adaptative a populației umane sunt reprezentate de înălbirea tegumentelor în urma migrației în zone mai reci și selecția fenotipurilor lactazo-persistente (12). Anual, se înregistrează peste 10 milioane de decese din cauza bolilor infecțioase și amenințarea unor noi epidemii și pandemii este mereu reconfirmată (13). Baza moleculară a proceselor care permit gazdei să recunoască patogenii și să declanșeze un răspuns adecvat o constituie expresia unor gene. Predispoziția genetică la infecții se manifestă atât în faza de recunoaștere a antigenului, cât și în faza de răspuns a organismului, fiind diferențiate polimorfisme ale genelor care codează proteinele implicate în recunoașterea patogenilor și polimorfisme genetice ale factorilor răspunsului inflamator. Altfel spus, susceptibilitatea pentru infecții este controlată genetic. Senzorii răspunsului inflamator sunt receptorii de suprafață celulară numiți toll-like receptors (TLRs), distribuiți la nivelul macrofagelor, celulelor dendritice, neutrofilelor și al altor celule. După cuplarea TLR cu molecule ale agentului infecțios, se produc semnale secvențiale complexe care duc la activarea factorului nuclear NF-kB, care, prin accesul la ",biblioteca ADN“, declanșează activarea genelor pentru efectorii imunitari.

Receptorii TLRs sunt considerați elemente cheie ale sistemului imun. Receptorii scanează mediul pentru a depista semnale de pericol reprezentate în principal de agenții microbieni şi inițiază cascada de semnale care mobilizează organismul pentru apărarea adecvată a gazdei. TLRs sunt proteine strâns înrudite structural care aparțin unei familii de receptori foarte vechi. În cursul evoluției, TLRs au suferit o selecție de purificare şi diversificare, probabil pentru a se adapta la semnalele microbiene produse de coevoluția germenilor (36).

Modul în care evoluția infecțiilor comune majore este afectată de genetica gazdei poate fi ilustrat de polimorfismele TLRs și ale TNF $\alpha$ (în tabelul 1).

\section{FACTORI CARE CONFERĂ REZISTENȚA LA INFECȚII}

Observațiile clinice au arătat că unele persoane sunt rezistente la infecțiile uzuale și la consecințele lor. Numai câțiva elevi contacți de streptococ $\beta$ hemolitic gr. A vor dezvolta reumatism articular acut sau glomerulonefrită acută. Puțini copii purtători de N. meningitidis vor prezenta boală meningococică invazivă. Nu- 
TABEL 1. Sumarul simplificat al principalelor polimorfisme genetice implicate în sepsis (2)

\begin{tabular}{|l|l|l|l|}
\hline Gena & Polimorfism & $\begin{array}{l}\text { Frecvența } \\
\text { alelelor }\end{array}$ & Consecințe \\
\hline TLR2 & -16933 T/A & & Bacteriemie, sepsis, şoc septic cu germeni Gram+ (St. aureus) \\
\hline TLR4 & $299 \mathrm{~A} / \mathrm{G}, 399 \mathrm{~T} / \mathrm{I}$ & $5 \%$ & Sepsis, şoc septic cu germeni Gram-; răspuns inflamator sever \\
\hline TLR5 & $392 \mathrm{~A} / \mathrm{T}$ & $7.5 \%$ & $\begin{array}{l}\text { Infecții } \text { E. coli, Ps. aeruginosa, favorizează corioamniotita şi } \\
\text { naşterile premature }\end{array}$ \\
\hline TNF $\alpha$ & TNF $\alpha$-308A & $18 \%$ & $\begin{array}{l}\text { Susceptibilitate şi mortalitate ridicată în şocul septic, } \\
\text { meningococemie, prognostic sever în infecții }\end{array}$ \\
\hline IL-6 & $\begin{array}{l}-174 G G, \text { alte } \\
\text { polimorfisme }\end{array}$ & $43 \%$ & $\begin{array}{l}\text { Niveluri scăzute, rol protector la bolnavii septici. Sepsis la } \\
\text { prematuri, disfuncție miocardică în meningococemie }\end{array}$ \\
\hline IL-10 & $592 \mathrm{~A}$ & $33 \%$ & Niveluri scăzute asociate cu creşterea mortalității în sepsis \\
\hline
\end{tabular}

mai 5-10\% dintre subiecții infectați cu $M$. tuberculosis dezvoltă boala; accidentele vaccinale cu germeni virulenți s-au soldat cu un număr de îmbolnăviri, dar o parte dintre copii au fost protejați în mod natural. Sunt cunoscuți sau în curs de investigare factorii genetici care conferă rezistență/susceptibilitate pentru malarie, hepatită B, tuberculoză, infecție HIV sau lepră. În infecția cu virus hepatitic $B$, răspunsul organismului este foarte variabil, deoarece numai o parte dintre bolnavi dezvoltă hepatită cronică. Pentru populația asiatică, prezența genelor HLA-DPA1 și HLA-DPB2 conferă rezistență la cronicizarea infecției, configurație care nu se întâlnește la populațiile caucaziene sau africane (14). Protecția este asigurată de haplotipuri din clasa II HLA, care asigură prezentarea particulelor virale și clearance-ul acestora, așa cum arată studii efectuate pe populația asiatică (15). Gena IL-28B codează pentru IFN-lambda; SNP al locusului pentru IL-28B influențează puternic răspunsul terapeutic cu IFN $\alpha$ în hepatita C; un beneficiu mai mare al acestui polimorfism îl au afro-americanii și populația hispanică (14). Între erorile înnăscute ale imunității, alelele mutante pot fi porți de intrare pentru patogeni sau pot avea un efect benefic la nivel individual sau populațional. Mutațiile autozomal recesive ale genelor DARC, CCR5 și FUT2 sunt legate de imunitatea protectoare pentru PI vivax, HIV și norovirus. Aceste gene codează receptori cheie de suprafața celulară pentru patogeni la suprafața eritrocitelor, celulele CD4 T sau ale epiteliului intestinal, prevenind intrarea agenților infecțioși în interiorul celulelor și replicarea acestora în organismul gazdei (16). Alelele mutante nu modifică rezistența globală a populației, însă expansiunea lor poate fi favorizată de avantajul selectiv pe care îl conferă față de un anumit microorganism sau față de infecții încă necunoscute (CCR5 și poate FUT2) (16). Probabil, există și ale mutații similare care s-au selectat pentru a oferi rezistență față de patogeni virulenți. Dintre studiile clinice, epidemiologice și genetice, cele mai cunoscute sunt cele care au evidențiat lipsa coreceptorului pentru patogen și, în consecință, la rezistență la infecție (17).

Homozigoții CCR delta 32 sunt imuni la SIDA, iar heterozigoții dezvoltă mai lent boala. S-a postulat că, înainte de apariția SIDA, alela delta-32 a putut oferi un avantaj selectiv față de patogeni din trecut (variola, ciuma) și că acum ar avea un rol protector față de un nou patogen; astfel, variola ar fi un candidat pentru presiune selectivă pe baza naturii retrovirale a virusului variolei și HIV (12). Deoarece Europa s-a confruntat cu epidemii devastatoare de variolă, selecția naturală ar explica faptul că aproximativ $16 \%$ din populația nord europeană deține alela delta-32, pe când în sud (4\% în Sicilia, 4,4\% în Grecia), Asia și Africa, procentul variază între 0 și 5\% $(12,18,19)$. Infecția produsă de Vibrio cholerae a afectat omenirea de mii de ani. Din cauza inundațiilor masive și frecvente, populația din Bangladesh a fost expusă endemiei de holeră din timpuri îndepărtate. Persoanele cu grupul sanguin $\mathrm{O}$ sunt cele mai susceptibile la infecții severe cu Vibrio cholerae. În Bangladesh, se înregistrează cea mai mică prevalență a grupului $O$ din lume, ca efect probabil al presiunii selective asupra populației $(20,21)$. O întrebare legitimă, cel puțin pentru SIDA, este dacă într-adevăr variantele genetice de rezistență la infecții sunt efectul selecției naturale sau reprezintă dispersia polimorfismelor genetice (mai mare de 5\% într-o populație) (12). Într-un studiu genetic asupra posibilei selecții naturale a populațiilor euroasiatice față de virusul HIV, Klemen-

TABEL 2. Mecanisme de rezistență naturală pentru unele infecții (17)

\begin{tabular}{|l|l|l|l|}
\hline Agent infecțios & Fenotip clinic & Fenotip imunologic & Gena \\
\hline PI vivax & Rezistența naturală & Lipsa coreceptorului pentru patogen & DARC \\
\hline Norovirus & Rezistența naturală & Lipsa coreceptorului pentru patogen & FUT2 \\
\hline Parvovirus & Rezistența naturală & Lipsa coreceptorului pentru patogen & $?$ \\
\hline HIV-1 & Rezistența naturală & Lipsa coreceptorului pentru patogen & CCR5 \\
\hline
\end{tabular}


tidis și colab. (22) confirmă modificările evolutive recente ale regiunilor genomice legate de imunitate în populația europeană și subliniază originea prin evoluție a factorilor care controlează infecția cu HIV. La scara evoluției populaționale, termenul "recent" ar putea fi considerat 700 de ani; posibil ca mutația CCR5-delta-32 să fi apărut datorată multiplelor episoade infecțioase din istorie (ex. ciuma bubonică a avut o mortalitate de $25-33 \%$ din populația Europei în intervalul 1346-1352), cu mult mai devreme, în jur de 1875 ani (23).

\section{IMUNITATEA ÎN INFECȚIILE CU CORONAVIRUSURI}

Coronavirusurile (CoVs) sunt un grup de virusuri care infectează oamenii (alături de alte specii virale) provocând infecții respiratorii. CoVs sunt încadrați în 4 genuri: Alfa CoVs (HcoV-NL63, HcoV-229), Beta CoVs (HcoV-OC43, SARS-CoV, HcoV-HKUI1 și MERS-CoV), Gama CoVs și Delta CoVs (24). Coronavirusurile sunt virusuri ARN caracterizate prin vârfuri în formă de crosă care se proiectează la nivelul suprafeței lor, un genom ARN neobișnuit de mare și o strategie unică de replicare. CoVs provoacă o varietate de boli la mamifere și păsări și infecții respiratorii umane cu potențial letal.

Înainte de izbucnirile epidemice recente produse de SARS-CoV și MERS-CoV, coronavirusurile produceau numai infecții respiratorii ușoare, autolimitate, asumând 15-30\% dintre infecțiile tractului respirator în fiecare an. Virulența coronavirusurilor a crescut semnificativ ulterior. SARS-CoV, agentul cauzal al sindromului respirator acut sever (SARS), a avut o rată ridicată de mortalitate $(15 \%)$ cu severitate ridicată la persoanele în vârstă (mortalitate 50\%) (24). Transmiterea virusului a fost redusă, fiind afectați mai ales contacții direcți la începutul bolii. Un nou virus a apărut în 2012 în unele țări arabe, MERS-CoV (middle east respiratory syndrome-CoV, MERS-CoV), înalt patogen pentru tractul respirator, a generat o mortalitate ridicată $\sim 50 \%$ la înce- putul epidemiei. Transmiterea acestuia a scăzut rapid, risipind temerile pentru o pandemie. Virusurile recente SARS-CoV, MERS-CoV și SARS-CoV-2, au metode comune de a suprima răspunsurile imune ale gazdei prin eschivare în fata detecției imune a celulelor (27). Coronavirusurile au în comun proteina $S$ (spike protein) și regiunea RBD (receptor binding domain), care interacționează cu receptorul celular uman, însă structura aminoacizilor care compun această proteină este specifică fiecărui tip de virus, ca și tipul de glicozilare al zaharurilor din compoziție (26). Componenta RBD a SARS-CoV-2 interacționează specific cu receptorul ACE2 al membranei celulare. Anticorpii care recunosc această parte a proteinei S previn parțial intrarea virusului în celulă (anticorpi neutralizanți) și contribuie alături de sistemul imun la eliminarea virusului din celulă (26). În cursul infecțiilor SARS-CoV, particulele de ARN dublu catenar (dsRNA) sunt ascunse în vezicule cu membrană dublă care funcționează ca un scut față de receptorii de recunoaștere (PRRs) prezenți la suprafața celulară (18). Intracelular, CoVs inhibă răspunsurile imunității înnăscute acționând în primul rând prin diminuarea inducției IFN (prin proteine ca ORF3,4,6) și a semnalelor produse de interferoni (27). Dinamica anticorpilor IgM (primii care apar), a IgG (răspuns imun consolidat) poate apărea diferit (numai IgG crescut) la persoane care au suferit o reinfecție sau ca răspuns (posibil) încrucișat cu o altă infecție cu CoV $(26,28)$. 80\% dintre pacienții infectați cu SARS-CoV-2 sunt asimptomatici sau au simptome ușoare, restul prezentând grade diferite de severitate. Este bine cunoscut faptul că infecțiile cu tulpini de coronavirusuri comune sunt foarte frecvente peste tot în lume, iar majoritatea donatorilor sănătoși de sânge au anticorpi împotriva coronavirusurilor; de aici ideea că acești anticorpi au putea fi protectori prin imunitate încrucișată față de antigenii SARS-CoV-2 (28). O altă explicație ar putea fi legată de fondul genetic al populației în care polimorfisme genetice ale sistemului HLA conferă mari diferențe în severitatea infecției cu SARS-CoV-2.

TABEL 3. Particularități ale susceptibilității genetice față de infecția cu SARS-CoV-2

\begin{tabular}{|l|l|c|}
\hline Structura genetică & Efecte & $\begin{array}{c}\text { Referința } \\
\text { bibliografică }\end{array}$ \\
\hline $\begin{array}{l}\text { Polimorfism al genei ACE: variabilitatea } \\
\text { alelelor I (inserție), D (deleție). Alela D } \\
\text { caracterizată prin reducerea expresiei ACE2 }\end{array}$ & $\begin{array}{l}\text { Prevalența infecțiilor corelată invers cu frecvența alelei D în } \\
\text { țrile din Europa Centrală şi de est. Corelație similară între } \\
\text { prezența alelei ACE D şi mortalitate }\end{array}$ & 29 \\
\hline $\begin{array}{l}\text { Ssistemul HLA prin alele implicate în } \\
\text { identificarea COVID-19 }\end{array}$ & $\begin{array}{l}\text { Alela HLA-B 46:01 capacitate scăzută de legare a peptidelor } \\
\text { COVID-19, forme severe de boală, încărcătură virală ridicată } \\
\text { Alela HLA-B 15:03 capacitate ridicată de a prezenta virusul, } \\
\text { favorizează dezvoltarea imunității }\end{array}$ & 30 \\
\hline Tipul de grup sanguin & $\begin{array}{l}\text { Grupa sanguină A, risc crescut de infectare cu COVID-19; } \\
\text { persoanele din grupa O au un risc de contaminare mai mic } \\
\text { cu 30\% față de grupul sanguin A în China }\end{array}$ & 31 \\
\hline
\end{tabular}




\section{INFLUENȚA IMUNITĂȚII DE TIP HETEROLOG}

În cazul infecției cu virusul Sars-CoV-2, 80\% dintre pacienții infectați rămân asimptomatici sau prezintă simptome respiratorii ușoare (32). Mai mult, în colectivități izolate, rata de îmbolnăvire nu a depășit $20 \%$ dintre subiecți sau chiar mai puțin. Noțiunea de imunitate heterologă provine din observația că expunerea la un patogen generează un răspuns imun față de numeroși epitopi (parte a unui antigen care este recunoscută de sistemul imunitar și se leagă de un anticorp) provenind de la un patogen, dar și un răspuns încrucișat față de epitopi provenind de la alți patogeni (33). În cursul infecției cu al doilea patogen, celulele cu memorie se înmulțesc rapid și pot domina răspunsul imun global (33). În SUA, o supraveghere prin RT-PCR a probelor din secrețiile respiratorii a pacienților a arătat că 4 coronavirusuri comune dețineau peste $3 \%$ dintre infecții în regiunile testate, însă coinfecția cu alte virusuri respiratorii se situa la $30 \%$ dintre cazuri (28). Studii serologice în diferite țări au pus în evidență că majoritatea donatorilor sănătoși de sânge aveau anticorpi față de coronavirusuri, dovedind că aceste infecții au avut o răspândire largă (28). O posibilă potrivire între epitopii coronavirusurilor comune la unii pacienți cu cele ale SARS-CoV-2 ar putea furniza o explicație pen- tru modul diferit de răspuns al acestora în pandemia de COVID-19. Într-un studiu efectuat în Japonia, autorii au analizat dacă epitopi formați din 9 aminoacizi ai SARS-CoV-2 sunt identici cu cei al unor tipuri de coronavirusuri umane benigne. Rezultatul a confirmat, într-adevăr, că unii dintre aceștia se pot lega de alele ale sistemului MHC-I, oferind un grad de memorie imună prin celule T CD8+ (28). Concordanța epitopilor poate reprezenta o cale de imunizare naturală prin prezența în populația receptivă a fracțiunilor proteice produse de infecțiile virale benigne. Cu toate acestea, COVID-19, strâns legat de echivalentul său zoonotic (similaritate 96,3\%), BatCoV RaTG13 (liliac) (34), deține căi ingenioase de adaptare la noua sa gazdă umană, având în curs de desfășurare variații dinamice; cel puțin pentru proteina spike - peste $15 \%$ (35).

\section{CONCLUZII}

Din ansamblul de date expuse, rezultă că răspunsul individual la infecțiile virale este influențat de genotipul gazdei prin polimorfisme genetice, de șansa unei imunități heterologe, dar construirea unei imunități puternice populaționale în fața unui virus cu multe fațete ca SARS-CoV-2 va trebui să aștepte o perioadă îndelungată.

Conflict of interest: none declared Financial support: none declared

\section{BIBLIOGRAFIE}

1. Chapman S, Hill A. Human genetic susceptibility to infectious disease. Nat Rev Gen. 2012;13:175-188.

2. Namath $A$, Patterson $A$. Genetic polymorphisms in sepsis. Crit Care Clin. 2009;25:835-856.

3. Akeel R. Role of epigenetic reprogramming of host genes in bacterial pathogenesis. Saudi J Biol Sci. 2013:20:305-309.

4. Sorensen $T$, Nielsen $G$, Andersen $P$. Genetic and environmental influences on premature death in adult adoptees. $N$ Engl J Med. 1988;18(12):727-732.

5. Petersen L, Nielsen G, Andersen P et al. Case-control study of genetic and environmental influences on premature death of adult adoptees. Genetic Epidemiol. 2002;23(2)123-132.

6. Obel N, Christensen K, Petersen L et al. Genetic and environmental influences on premature death due to infections assesed in Danish twins, 1943-2001. Am J Epidemiol. 2010;17(9):1007-1013.

7. Sapru A, Quasney M. Host Genetics and Pediatric Sepsis. Open Infl J. 2011;4(Suppl 1-M10):82-100

8. Li JZ, Absher DM, Tang $\mathrm{H}$ et al. Worldwide human relationships inferred from genome-wide patterns of variation. Science. 2008;319(5866):1100-1104.

9. Lederberg J. J.B.S. Haldane (1949) on infectious disease and evolution. Genetics. 1999;153(1):1-3.

10. Galvani AP, Slatkin M. Intense selection in an age-structured population. Proc Biol Sci. 2004;271(1535):171-176.

11. Burgner D, Jamieson S, Blackwell J. Genetic susceptibility to infectious diseases: Big is beautiful, but will bigger be even better? Lancet Infect Dis. 2006;6(10):653-663.

12. Novembre J, Han E. Human population structure and the adaptive response to pathogen-induced selection pressures. Philos Trans R Soc Lond B Biol Sci. 2012;367(1590):878-86.

13. Hill AV. Evolution, revolution and heresy in the genetics of infectious disease susceptibility. Philos Trans $R$ Soc Lond $B$ Biol Sci. 2012;367(1590):840-849.

14. Nishida N, Sawai H, Matsuura K et al. Genome-wide Association Study Confirming Association of HLA-DP With Protection Against Chronic Hepatiits B and Viral Clearance in Japanese and Korean. PloS One. 2012;7(6):e39175.
15. Kamatani Y, Wattanapokayakit S, Ochi $\mathrm{H}$ et al. A genome-wide association study identifies variants in the HLA-DP locus associated with chronic hepatitis $B$ in Asians. Nat Genet. 2009;41(5):591-595.

16. McCarty C. Immunology Essential and Fundamental. Tech Press UK, 2018.

17. Alcais A, Abel L, Casanova JL. Human genetics of infectious diseases: Between proof of principle and paradigm. J Clin Invest. 2009;119:2506-2514.

18. Galvani AP, Novembre J. The evolutionary history of the CCR5-Delta32 HIV-resistance mutation. Microbes Infect. 2005;7(2):302309.

19. Solloch UV, Lang K, Lange V, Böhme I, Schmidt AH, Sauter J. Frequencies of gene variant CCR5- $\Delta 32$ in 87 countries based on next-generation sequencing of 1.3 million individuals sampled from 3 national DKMS donor centers. Hum Immunol. 2017;78(1112):710-717.

20. Pittman KJ, Glover LC, Wang L, Ko DC. The Legacy of Past Pandemics: Common Human Mutations That Protect against Infectious Disease. PLoS Pathog. 2016;12(7):e1005680. 
21. Glass R, J Holmgren, Haley $\mathrm{C}$ et al. Predisposition for Cholera of Individuals With O Blood Group. Possible Evolutionary Significance. Am J Epidemiol. 1985;121(6):791-796.

22. Klementidis $Y$, Aissani B, Shriver M et al. Natural selection among Euroasian at genomic regions associated with HIV-1 control. Evolutionary Biol. 2011;11:173.

23. Stephens J, Reich D, Goldstein D et al. Dating the Origin of the CCR5-delta32 AIDS-Resistance Allele by the Coalescence of Haplotypes. Am J Genet. 1998;62:15071515.

24. Fehr A, Perlman S. Coronaviruses: An Overview of Their Replication and Pathogenesis. In $\mathrm{H}$ Maier et al (eds). Coronaviruses: Methods and Protocols, Methods in Molecular Biology, vol. 1282, Springer, New York, 2015.

25. Thompson M, Kaminski J, Kurt-Jones E, Fitzgerald K. Pattern Recognition Receptors and the Innate Immune Response to Viral Infection. Viruses. 2011;3:920-940

26. Suthar M, Zimmerman M, Kauffman R et al Rapid generation of neutralizing antibody responses in COVID-19 patients. medRxiv http://doi.org/100.
27. Kumar A, Nyodu R, Maurya V, Saxena S. Host Immune response and immunobiology of Human SARS-CoV-2 Infection. In Saxena (Ed) Coronavirus Disease 2019, Medical Virology: from Pathogenesis to Disease Control, http://doi.org/10.1007/978981-15-4814-7_5.

28. Dijkstra J, Hashimoto K. Expected immune recognition of COVID-19 virus by memory from earlier infections with common coronaviruses in a large part of the world population. F1000Research. 2020;9:285.

29. Delanghe JR, Speeckaert MM, De Buyzere $\mathrm{ML}$. The host's angiotensin-converting enzyme polymorphism may explain epidemiological findings in COVID-19 infections. Clin Chim Acta. 2020;505:192193.

30. Godri Pollitt KJ, Peccia J, Ko Al et al. COVID-19 vulnerability: The potential impact of genetic susceptibility and airborne transmission. Hum Genomics 2020;14:17.

31. Zhao J, Yang $\mathrm{Y}$, Huang $\mathrm{H}$ et al. Relationship between the ABO Blood Group and the COVID-19 Susceptibility. medRxiv 2020.03.11.20031096.

32. Sahoo S, Hari K, Jhunjhunwala S, Jolly M. Mechanistic modeling of the SARS-CoV-2 and immune system interplay unravels design principles for diverse clinicopathological outcomes. bioRxiv preprint doi:http://doi. org/10.1101/2020.05.16.097238.

33. 3Rouse BT, Sehrawat S. Immunity and immunopathology to viruses: What decides the outcome? Nat Rev Immunol. 2010;10(7):514-26.

34. Paraskevis D, Kostaki EG, Magiorkinis G, Panayiotakopoulos G, Sourvinos G, Tsiodras S. Full-genome evolutionary analysis of the novel corona virus (2019-nCoV) rejects the hypothesis of emergence as a result of a recent recombination event. Infect Genet Evol. 2020;79:104212.

35. van Dorp L, Acman M, Richard D, Shaw LP, Ford CE, Ormond L, Owen CJ, Pang J, Tan CCS, Boshier FAT, Ortiz AT, Balloux F. Emergence of genomic diversity and recurrent mutations in SARS-CoV-2. Infect Genet Evol. 2020;83:104351.

36. Malagoli $D$ (ed.). The Evolution of the Immune System. Academic Press, 2016. 